Revista Cientifica do Instituto Agronômico, Campinas

\title{
ESVERDEAMENTO E BROTAÇÃO EM CULTIVARES ALEMÃES E HOLANDESES DE BATATA ${ }^{(1)}$
}

Iairo lopes de Castro (2) e Hilário da Silva Miranda Filho, Seção de Raízes e Tubérculos, e Joassy de PaULA Neves JoRge (2), Divisão de Plantas Alimentícias Básicas, Instituto Agronômico.

0 esverdeamento de tubérculos de batata (Solanum tuberosum L.), além de ser prejudicial à saúde, pela ocorrência de formação de solanina, alcalóide inibidor da colinesterase, deprecia 0 produto na comercialização $(3,4)$. A lavagem dos tubérculos e sua exposição à luz solar, na comercialização em feiras livres, ou mesmo em sacos rendilhados, de náilon, nos supermercados, favorecem esse esverdeamento (1). 0 início e a velocidade de desenvolvimento da brotação dependem do cultivar, grau de maturação do tubérculo colhido, condições de armazenamento, injúrias mecânicas, doenças fúngicas ou bacterianas e danos causados por insetos (2). A precocidade de brotação é característica desejada na escolha do cultivar em regiōes onde se realiza mais de um plantio por ano e as batatas-semente utilizadas no segundo plantio são oriundas do cultivo anterior. Os cultivares tardios sāo os preferidos em regióes de apenas um plantio anual, pelo fato de os tubérculos colhidos poderem ser conservados em melhores condições fisiológicas, durante um período mais prolongtado. 0 presente trabalho teve como objetivo selecionar cultivares de batatas alemães e holandeses menos suscetíveis ao esverdeamento, e também classificá-los em relação a precocidade de brotação.

Material e métodos: As observações de esverdeamento e brotação foram realizadas em tubér-

(I) Recebida para publicaçāo a 8 de setembro de 1981.

(') Com bolsa de suplementação do CNPq. 
culos recém-colhidos de um ensaio de competição de cultivares estrangeiros de batata, cinco holandeses e dezenove alemāes, realizado no município de Piedade (SP). Os tubérculos foram colhidos a 25 de maio de 1973 e, após pesagem e classificação em tipos, tomados cem de cada cultivar, com peso médio de $60 \mathrm{~g}$, tipo primeira.

0 material, inicialmente armazenado em sala escura, em pequenas caixas de madeira com aberturas laterais para ventilação, durante seis dias, a $10^{\circ}$ de junho foi colocado em ambiente de luz difusa, semelhante ao dos armazéns e supermercados, onde os tubérculos não recebem luz solar direta. Para facilitar a leitura do esverdeamento, dez tubérculos por cultivar foram espetados na região da inserção do estolho, em pregos fixados em ripas de madeirá. Em um dos tubérculos, na região do broto apical, foi colocada, em forma de cruz, fita adesiva isolante, de cor preta, com a finalidade de conservar a coloração inicial da película e permitir comparações.

As observações foram tomadas quatro vezes, de cinco em cinco dias, através da seguinte escala de notas: 1 . sem esverdeamento; 2. ligeiramente esverdeado ; 3 . moderadamente verde; 4 . verde; 5 . muito verde. Para as observaçōes de brotação, os tubérculos foram mantidos nas caixas de madeira $\mathrm{e}$ as leituras efetuadas de dez em dez dias, com escala de 1 a 5 , até que quase todas as amostras apresentassem ótima brotação para plantio, isto é, brotos apicais com primórdios radiculares e início de formação de folíolo. Os pontos da escala foram os seguintes: 1. sem brotação; 2 . início de brotação (até $3 \mathrm{~mm}$ ); 3. brotada (de 3 a $6 \mathrm{~mm}$ ) ; 4 . bem brotada (de 6 a $10 \mathrm{~mm}$ ); 5. com ótima brotação (maior que $10 \mathrm{~mm}$ ).

Resultados e discussão: As leituras de esverdeamento são apresentadas no quadro 1 . Os cultivares holandeses Jaerla e Bintje foram os menos suscetíveis ao esverdeamento. Dentre os alemães, Atica, Emergo e Topi sobressaíram sobre os demais que, após a segunda leitura, já se mostravam verdes ou muito verdes. Os cultivares Jetta, Broca, Wiebke, Palma, Lux, Rubin e Salvia, desde a primeira leitura apresentavam-se de verdes a muito verdes.

$O$ quadro 2 mostra o desenvolvimento $\mathrm{da}$ brotação durante quatro meses. Os cultivares mais precoces de brotação foram Omega, Jaerla e Bintje, sendo que no último o desenvolvimento foi mais lento. Os mais tardios foram: Geelbling, Salvia e Spunta. 
QUADRO 1 - Valores médios das leituras do esverdeamento, em tubérculos de cultivares de batata holandeses (H) e alemäes, realizadas de cinco em cinco dias (1)

\begin{tabular}{|c|c|c|c|c|}
\hline \multirow{2}{*}{ Cultivares } & \multicolumn{4}{|c|}{ Datas das leituras } \\
\hline & $5 / 6$ & $10 / 6$ & $15 / 6$ & $20 / 6$ \\
\hline Jaerla (H) & 1,0 & 1,0 & 1,5 & 1,5 \\
\hline Bintje (H) & 2,0 & 2,5 & 2,5 & 3,5 \\
\hline Marijke (H) & 2,0 & 3,5 & $\mathbf{3 , 5}$ & 3,5 \\
\hline Atica & 2,0 & $\mathbf{3 , 5}$ & $\mathbf{3 , 5}$ & $\mathbf{3 , 5}$ \\
\hline Topi & 2,0 & $\mathbf{3 , 5}$ & 4,5 & 5,0 \\
\hline Emergo & 2,5 & 3,5 & $\mathbf{3 , 5}$ & 4,5 \\
\hline Omega & 2,0 & 4,0 & 4,0 & 4,5 \\
\hline Spunta (H) & 2,5 & 4,0 & 4,0 & 4,5 \\
\hline Umbra & 3,0 & 4,0 & 4,5 & 4,5 \\
\hline Prinzess & 3,5 & 4,0 & 4,0 & 4,5 \\
\hline Ceres & 2,5 & 4,5 & 4,5 & 4,5 \\
\hline Geelbling & 3,0 & 4,0 & 4,5 & 5,0 \\
\hline Prima & $\mathbf{3 , 5}$ & 4,5 & 4,5 & 4,5 \\
\hline Baku & 3,0 & 4,5 & 5,0 & 5,0 \\
\hline Bola & 3,0 & 4,5 & 4,5 & 5,0 \\
\hline Jetta & 4,0 & 4,5 & 4,5 & 4,5 \\
\hline Ulla & 3,5 & 4,5 & 5,0 & 5,0 \\
\hline Humalda (H) & 3,0 & 5,0 & 5,0 & 5,0 \\
\hline Broca & 4,0 & 4,5 & 5,0 & 5,0 \\
\hline Wieble & 4,0 & 5,0 & 5,0 & 5,0 \\
\hline Palma & 4,0 & 5,0 & 5,0 & 5,0 \\
\hline Lux & 4,5 & 5,0 & 5,0 & 5,0 \\
\hline Rubin & 4,5 & 5,0 & 5,0 & 5,0 \\
\hline Salvia & $\mathbf{4 , 5}$ & 5,0 & 5,0 & 5,0 \\
\hline
\end{tabular}

(1) Escala de pontos: 1: sem esverdeamento; 2: ligeiramente esverdeato; 3 : moderadamente verde; $4:$ verde; 5 : muito verde. 
Vol. 41 , Nota n. ${ }^{\circ} 3$

QUADRO 2 - Valores do estádio de brotação de tubérculos de cultivares de batata holandeses (H) e alemăes, observados de dez em dez dias (1)

Cultivares

Datas das leituras

\begin{tabular}{|c|c|c|c|c|}
\hline $20 / 6$ & $30 / 6$ & $10 / 7$ & $20 / 7$ & 8 \\
\hline
\end{tabular}

\begin{tabular}{|c|c|c|c|c|c|c|c|c|c|}
\hline Geelbling & 1 & 1 & 1 & 1 & 1 & 1 & 1 & 2 & 3 \\
\hline Salvìa & 1 & 1 & 1 & 1 & 1 & 2 & 2 & 2 & 3 \\
\hline Spunta (H) & 1 & 1 & 1 & 1 & 1 & 2 & 3 & 4 & 5 \\
\hline Ceres & 1 & 1 & 1 & 2 & 2 & 2 & 3 & 4 & 4 \\
\hline Ula & 1 & 1 & 1 & 2 & 2 & 3 & 3 & 4 & 5 \\
\hline Palma & 1 & 1 & 1 & 2 & 2 & 3 & 5 & 5 & 5 \\
\hline $\operatorname{Lux}$ & 1 & 1 & 1 & 2 & 3 & 4 & 4 & 5 & 5 \\
\hline Humalda (H) & $\mathbf{I}$ & 1 & 2 & 2 & 2 & 2 & 3 & 4 & 5 \\
\hline Rubin & 1 & 1 & 2 & 2 & 3 & 4 & 5 & 5 & 5 \\
\hline Broca & 1 & 1 & 2 & 3 & 3 & 4 & 5 & 5 & 5 \\
\hline Marijke (H) & 1 & 2 & 2 & 2 & 2 & 3 & 4 & 4 & 5 \\
\hline Topi & 1 & 2 & 2 & 3 & 3 & 4 & 4 & 4 & 5 \\
\hline Prima & 1 & 2 & 3 & 4 & 4 & 4 & 5 & 5 & 5 \\
\hline Umbra & 2 & 2 & 2 & 2 & 2 & 2 & 3 & 4 & 4 \\
\hline Atica & 2 & 2 & 2 & 2 & 3 & 4 & 4 & 5 & 5 \\
\hline Wiebke & 2 & 2 & 2 & 3 & 3 & 3 & 4 & 5 & 5 \\
\hline Baku & 2 & 2 & 2 & 3 & 3 & 4 & 4 & 4 & $\mathbf{5}$ \\
\hline Emergo & 2 & 2 & 3 & 4 & 4 & 4 & 4 & 4 & $\mathbf{5}$ \\
\hline Jetta & 2 & 2 & 3 & 4 & 4 & $\mathbf{5}$ & 5 & 5 & 5 \\
\hline Prinzess & 2 & 2 & 3 & 4 & 5 & 5 & 5 & 5 & 5 \\
\hline Bintje (H) & 2 & 3 & 3 & 3 & 3 & 3 & 3 & 4 & 5 \\
\hline Jaerla (H) & 8 & 3 & 4 & 5 & 5 & 5 & 5 & 5 & 5 \\
\hline Omega & 3 & 4 & 4 & $\mathbf{5}$ & $\mathbf{5}$ & 5 & 5 & 5 & 5 \\
\hline
\end{tabular}

(1) Escala de pontos: 1: sem brotação; 2: início de brotação (até $3 \mathrm{~mm}$ ); 3: brotada (de 3 a $6 \mathrm{~mm}$ ); 4: bem brotada (de 6 a $10 \mathrm{~mm}$ ); 5: com 6tima brotaçâo (maior que 10mm). 


\section{Março, 1982 ESVERDEAMENTO E BROTAÇÃO EM BATATA \\ 207 \\ OBSERVATIONS ON GREENING AND SPROUT GROWTH IN GERMAN AND DUTCH POTATO VARIETIES}

\section{SUMMARY}

Nineteen German and five Dutch potato varieties were observed in relation to greening and sprout growth development in the tubers.

The Dutch varieties Jaerla and Bintje and the German varieties Atica, Emergo and Topi were less susceptible to greening, but all the others in the second reading, 10 days after light exposition, showed the skin green or very green. Jetta, Broca, Wiebke, Palma, Lux, Rubin and Salvia, 5 days after light exposition also showed similar results.

The varieties that showed early sprout growth were Omega, Jaerla and Bintje, being the latter slower in relation to development. Geelbling, Salvia and Spunta are late sprout growth varieties.

\section{REFERENCIAS BIBLIOGRAFICAS}

1. BAERUG, R. Influence of different rates and intensities of light on solanine content and cooking quality of potato tubers. European Potato Journal, 5:242-251, 1962.

2. BEUKEMA, H. P. Dormancy and sprout growth. In: INTERNATIONAL COURSE OF POTATO PRODUCTION, 1., Wageningen, Holanda. p.5-12.

3. BOOCK, O. J. Instruçōes para a cultura da batatinha. Campinas, Instituto Agronômico, 1963. 35p. (Boletim, 128)

4. ORGeL, W. H.; VAIDYA, K. A.; DAHM, P. A. Cholinesterase inhibition in vitro by extracts of potato. Proceedings of the Iowa Academy of Science, 65:160-162, 1958. 